\title{
Microstructure - Properties Relationships in Carbide-free Bainitic Steels
}

\author{
Jean-Christophe HELL, ${ }^{1) *}$ Moukrane DEHMAS, ${ }^{2)}$ Sébastien ALLAIN, ${ }^{3)}$ Juscelino Mendes PRADO, ${ }^{3)}$ \\ Alain HAZOTTE" ${ }^{1)}$ and Jean-Philippe CHATEAU ${ }^{21}$
}

1) Laboratoire d'Etude des Microstructures et de Mécanique des Matériaux - LEM3, UMR CNRS 7239, Université Paul Verlaine Metz, Ile du Saulcy, 57045 Metz, France. E-mail: jean-christophe.hell@univ-metz.fr, alain.hazotte@univ-metz.fr

2) Institut Jean Lamour - IJL, UMR CNRS 7198, Ecole des Mines de Nancy, Parc de Saurupt, 54042 Nancy, France.

3) ArcelorMittal Research Maiziéres, Voie romaine, 57283 Maizières-Lès-Metz, France.

(Received on May 6, 2011; accepted on July 5, 2011)

\begin{abstract}
We elaborated two carbide-free bainitic steels with different microstructures through specific alloy design and austempering process. Microstructural characterizations were performed by means of EBSD analysis and in-situ high energy synchrotron diffraction in order to evaluate the phase fractions and the carbon content in the retained austenite, as well as the microtextures. These microstructural features were correlated to the tensile properties. Both steels exhibited an excellent compromise between high strength (above $1250 \mathrm{MPa}$ ), good ductility (uniform elongation up to 14\%) and high fracture strain (reduction of area up to $46 \%$ ). The volume fraction of MA blocks (blocks of retained austenite partially transformed into fresh martensite during the final cooling at room temperature) was a key relevant parameter that strongly influenced the work-hardening at the expense of the damaging processes at high strain.
\end{abstract}

KEY WORDS: carbide-free bainite; retained austenite; microstructure; microtexture; carbon content; tensile properties; work-hardening; ductility.

\section{Introduction}

3rd generation of Advanced High Strength Steels (AHSS) is a generic term referring to steels with various innovative microstructures, which are intensively studied by many research teams (steelmakers and academics) to propose a breakthrough alternative offer in the flat and long carbon market (Fig. 1). ${ }^{1-3)}$ Advanced alloy design and non-conventional annealing process allow to reach tensile strengths above 1000 $\mathrm{MPa}$ as well as good formability and ductility. The design of such steels is also achieved by limited additions of gammastabilizers (C, Mn, Ni, Cu) in "modern steels", whereas they significantly differ from 2nd generation of AHSS, which are fully austenitic thanks to very high amount of $\mathrm{Mn}$.

Amongst these ground-breaking materials, the most attractive are likely Carbide-Free Bainitic (CFB) steels (TRansformation Induced Plasticity (TRIP) steels with bainitic matrix), TRIP steels with annealed martensitic matrix and quenching and partitioning martensitic steels. They all exhibit similar features:

- Their chemical compositions are similar to those of ferritic TRIP steels, but with higher contents of gammafavoring elements $(\mathrm{Mn}, \mathrm{Ni}$, and $\mathrm{Cu}$ ).

- Their specific ductility is obtained thanks to the metastability of retained austenite, which promotes a possible TRIP effect. An increase of their carbon content allows improved tensile resistance but also enhanced uniform elongation.

- They bear high internal stresses, thanks to the ultra-fine lamellar morphology of the matrix (bainite or martensite) and as a consequence, exhibit good resistance to damage (high fracture strain).

Therefore, they differ mainly by the type and the morphology of their matrix, as well as the state of the retained austenite. In this paper, we focus on CFB steels. Their interests are manifold since they combine promising tensile behavior with improved in-use properties, as reported by previous researches. ${ }^{4-12)}$

Their mechanical behavior is strongly impacted by the characteristics of their microstructures. Indeed, the bainitic

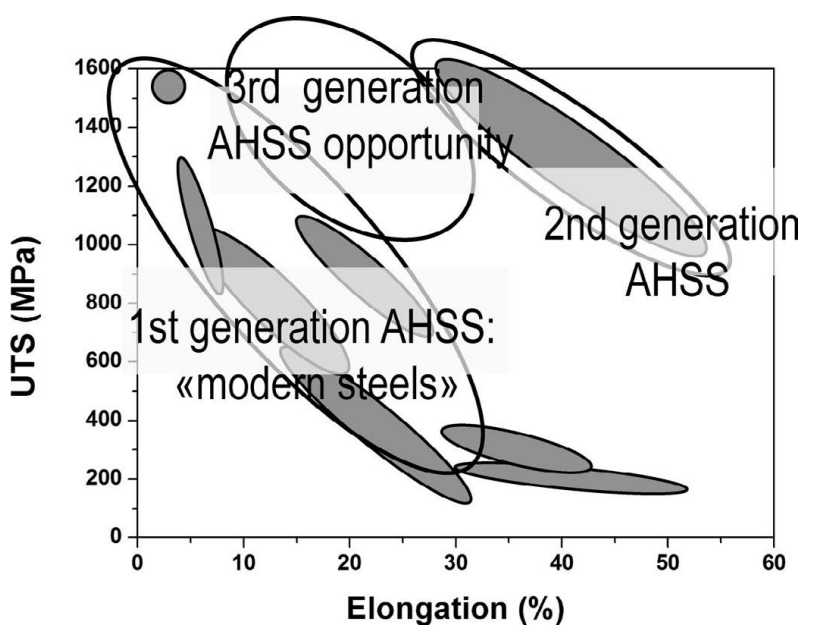

Fig. 1. Opportunity for 3rd generation of AHSS. 
transformation is one of the most complex phase transformations in steels and can lead to various microstructures exhibiting different mechanical behaviors. Therefore it is essential to better understand the relationships between significant microstructural features and the mechanical behavior of such steels. The main goals of this work consist in:

- Elaborating various carbide-free bainitic microstructures (volume fractions, lath size, topological characteristics of phases ...) by different heat treatments;

- Quantitatively analyzing the resulting microstructures;

- And finally linking them with their tensile behavior.

\section{Experimental}

\subsection{Alloy Design}

The design of the CFB steels was performed with regards to numerous previous works on such steels, especially Sugimoto's, ${ }^{6,7)}$ who studied the effect of carbon and manganese contents on the characteristics of the retained austenite and on the in-use properties. First, a high content of silicon $(\geq 1.5 \% \mathrm{wt})$ was required to postpone the precipitation of carbides (cementite) during the bainitic transformation. The manganese content was fixed in reference to Sugimoto's works, in which a content of $2.5 \%$ wt allows reaching ultimate tensile strength above $1200 \mathrm{MPa}$. Significant amounts of chromium were added to promote a lamellar bainitic matrix without forming allotriomorphic ferrite during the cooling after a full austenitization. Two heats with different carbon contents were elaborated. Their compositions are given in Table 1. The carbon contents were chosen in order to match those of classical ferritic TRIP steels and to vary the transformation kinetics and inherited phase fractions.

The steels were elaborated using a $60 \mathrm{~kg}$ vacuum induction furnace under inert atmosphere at ArcelorMittal Maizières Research. Pure ( $>99.9 \%$ ) electrolytic iron was

Table 1. Compositions of the studied steels and Ms temperatures measured by dilatometry.

\begin{tabular}{cccccc}
\hline Steel & $\mathrm{C}(\% \mathrm{wt})$ & $\mathrm{Mn}(\% \mathrm{wt})$ & $\mathrm{Si}(\% \mathrm{wt})$ & $\mathrm{Cr}(\% \mathrm{wt})$ & $\mathrm{Ms}\left({ }^{\circ} \mathrm{C}\right)$ \\
\hline $\mathrm{C} 2$ & 0.2 & 2.5 & 1.5 & 0.8 & 380 \\
$\mathrm{C} 3$ & 0.3 & 2.5 & 1.5 & 0.8 & 330 \\
\hline
\end{tabular}

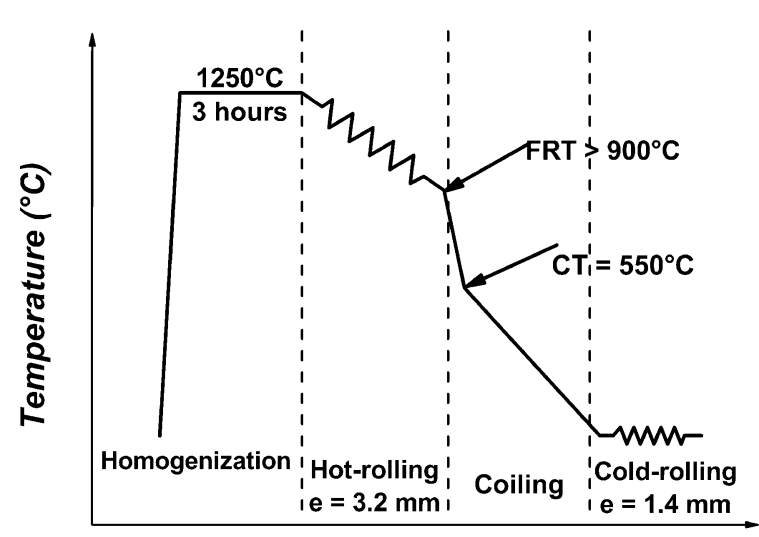

Time (S)

Fig. 2. Schematic thermomechanical process to produce steel sheets before austempering treatment. used with successive additions of the alloying elements. Carbon desoxydation was performed and an analysis of $\mathrm{C}$, $\mathrm{S}, \mathrm{N}$ and $\mathrm{O}$ was made on line during elaboration for the final adjustment of composition. The elaborated ingots were further heat treated at $1250^{\circ} \mathrm{C}$ during three hours to reduce any alloying element microsegregation. The ingots were hotrolled with a coiling temperature of $550^{\circ} \mathrm{C}$, then grinded to remove decarburized layer and cold-rolled to produce 1.4 mm gauge thickness strips (Fig. 2).

\subsection{Heat Treatments}

Several annealing treatments were applied after cold-rolling. Austenitization conditions were chosen in order to produce large austenitic grains, which will promote coarse microstructures with elongated bainite laths. The influence of austenitization temperature on the austenitic grain size was investigated by thermal etching. ${ }^{13,14)}$ It consisted of applying the austenitization process on a finely polished sample. The formation of the austenitic grains led to the formation of grooves at the intersection of the polished surface and the grain boundaries. These grooves were kept intact after cooling and therefore were easily visible at room temperature. Moreover, a thin layer of oxides was formed on the polished surface during gas cooling, which gave significant contrast and allowed observing thermal twins in the austenitic grains. The average austenitic grain size was estimated by the grain counting method. The austenitization conditions $\left(10\right.$ minutes at $\left.1080^{\circ} \mathrm{C}\right)$ were chosen as a compromise for both steels to present an average austenitic grain size of approximately $30-40 \mu \mathrm{m}$.

The austempering conditions were investigated by various dilatometric trials. Kinetics of the bainitic transformation was studied at three austempering temperatures (AT), $\mathrm{Ms}-50^{\circ} \mathrm{C}$, Ms and $\mathrm{Ms}+50^{\circ} \mathrm{C}$ (Ms: martensite start temperature). In the AT range tested, different microstructures could be generated in terms of phase fractions, microtextures and carbon content of the retained austenite. Moreover, investigations of the kinetics of the transformation revealed an incomplete reaction phenomenon, ${ }^{15,16)}$ as already reported in these kinds of microstructures. ${ }^{17,18)}$ The bainitic transformation was quite slow to reach its stasis at such temperatures. Therefore, dwell times were set to 40 minutes. Figure 3 schematizes the applied heat treatments.

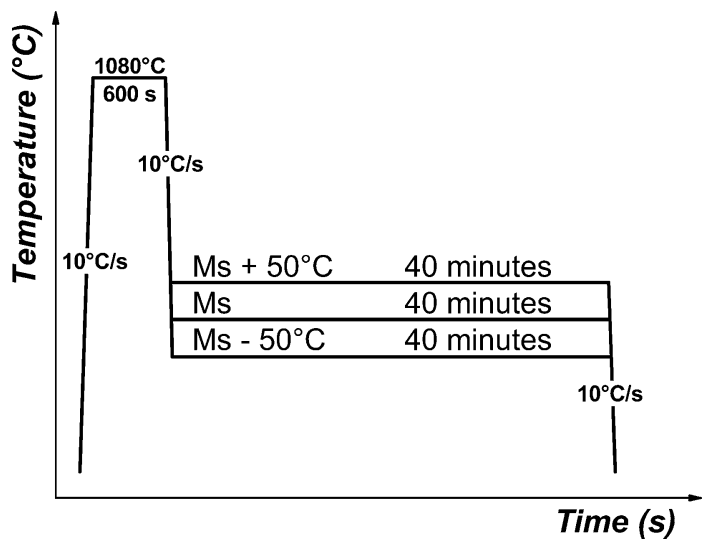

Fig. 3. Annealing treatments applied to the steels to obtain various microstructures containing carbide-free bainite, retained austenite and self-tempered martensite. 


\subsection{Microstructural and Mechanical Characteriza- tions}

Microstructural investigations were performed by several methods, such as scanning electron microscopy, Electron BackScatter Diffraction (EBSD) analysis and synchrotron X-Ray Diffraction (XRD). A JEOL 6500F FEG-SEM was used to investigate the microstructures. EBSD analyses were performed after adequate surface preparation, with the HKL Oxford Instrument system. Orientation maps with a beam step of $80 \mathrm{~nm}$ were acquired. They covered an average area of about $160 \times 120 \mu \mathrm{m}^{2}$ (i.e. 3 to 4 whole prior austenitic grains). The Kikuchi Pattern Quality (KPQ) maps were also used to observe the microstructure.

XRD experiments were performed at the European Synchrotron Radiation Facility (ESRF) in Grenoble, France on the ID15B beamline. In-situ measurements were performed by high energy X-ray synchrotron diffraction using a monochromatic $88 \mathrm{keV}$ beam $\left(500 \times 400 \mu \mathrm{m}^{2}\right)$. A 2D image plate detector, placed at $900 \mathrm{~mm}$ from the sample allowed acquiring 5 complete rings for the austenite. These patterns were acquired every $0.25 \mathrm{~s}$ at the beginning of the transformation and every $4 \mathrm{~s}$ after 10 minutes. In order to obtain the classical $2 \theta$ scans suitable for Rietveld analysis, the intensity of each ring was integrated.

Tensile tests were performed under normalized conditions, i.e. at room temperature and under low strain rate (1.2 $10^{-3} \mathrm{~s}^{-1}$ ) on a Zwick/Roell tensile device equipped with a high precision video-extensometer. Figure 4 schematizes the non-normalized sample geometry.

\section{Results}

\subsection{Microstructural Investigations}

The results of the microstructural investigations are summarized in Table 2. In-situ characterization by high energy synchrotron diffraction allowed us to quantify the evolution of volume fraction and cell parameter of each phase ${ }^{19)}$ using the Rietveld method to process the data. ${ }^{20)}$

Since the diffraction peaks of bainitic ferrite and martensite overlapped, distinction of volume fractions was based on a kinetic criterion. Indeed, for AT below Ms, martensite rapidly formed during the cooling before the $\mathrm{AT}$ is reached. This freshly formed martensite was tempered during the austempering stage (Fig. 5 shows the precipitation of carbides in the martensitic laths), while an isothermal transformation occurred simultaneously. The nature of this transformation is controversial. Some authors attribute it to the formation of an isothermal martensite, ${ }^{21)}$ whereas others

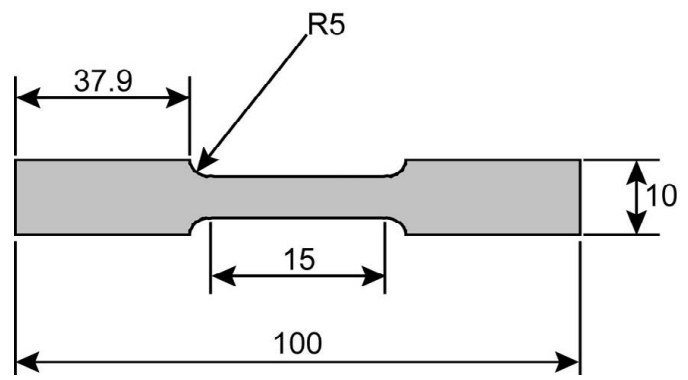

Fig. 4. Scheme of the tensile test specimens (quotations are given in $\mathrm{mm}$ ). ascertain it to be a bainitic transformation. ${ }^{22)}$ We observed a continuous increase of the austenitic cell parameter as the isothermal transformation proceeded. Such observations were consistent with a mechanism based on the rejection of carbon from the bainitic ferrite into the remaining austenite, as reported in previous works on the bainitic transformation. ${ }^{23,24)}$ Moreover, austempering treatments performed at $\mathrm{Ms}$ and $\mathrm{Ms}+50^{\circ} \mathrm{C}$ showed the same evolution of the austenitic cell parameter. In the following, we will thus consider the product of the isothermal transformation as a bainitic phase. Therefore, it is possible to assess the respective volume fractions of tempered martensite $\left(\alpha_{s t}\right)$ and bainitic ferrite $\left(\alpha_{B}\right)$ formed at the end of the austempering stage, since the kinetics of these transformations were distinct. Finally, the volume fraction of fresh martensite $\left(\alpha^{\prime}\right)$, formed during the final cooling at room temperature, was calculated by the difference between the volume fractions of retained austenite $\left(\gamma_{R}\right)$ at the end of the bainitic transformation and at room temperature.

XRD data could not be used to calculate the carbon content of the austenite from the lattice parameter. Indeed, the positions of the diffraction peaks were strongly dependent on the calibration of the equipment settings (beam wavelength, sample - detector distance, beam center ...). Therefore, lattice parameter calculated values should not be used in absolute terms because of their great sources of errors. However, they could be used trustfully in relative terms in order to investigate their evolution as the transformation

Table 2. Volume fractions (\%) of bainitic ferrite $\left(\alpha_{B}\right)$, retained austenite $\left(\gamma_{R}\right)$, self-tempered martensite $\left(\alpha_{S T}\right)$, and fresh martensite $\left(\alpha^{\prime}\right)$, in the elaborated steels and carbon content in the retained austenite $C_{\gamma}^{C}(\% \mathrm{wt})$.

\begin{tabular}{clrrrrr}
\hline Steel & \multicolumn{1}{c}{$\mathrm{AT}$} & \multicolumn{1}{c}{$\alpha_{B}$} & $\gamma_{R}$ & $\alpha_{S T}$ & $\alpha^{\prime}$ & $C_{\gamma}^{C}$ \\
\hline \multirow{2}{*}{$\mathrm{C} 2$} & $\mathrm{Ms}-50^{\circ} \mathrm{C}$ & 26.0 & 11.3 & 62.3 & 0.4 & 0.64 \\
& $\mathrm{Ms}$ & 77.3 & 15.1 & 4.2 & 3.4 & 1.04 \\
& $\mathrm{Ms}+50^{\circ} \mathrm{C}$ & 53.2 & 7.4 & - & 39.4 & 0.43 \\
& $\mathrm{Ms}-50^{\circ} \mathrm{C}$ & 18.5 & 18.3 & 62.1 & 1.1 & 0.59 \\
$\mathrm{C} 3$ & $\mathrm{Ms}$ & 76.9 & 15.3 & 3.4 & 4.4 & 1.47 \\
& $\mathrm{Ms}+50^{\circ} \mathrm{C}$ & 63.3 & 21.5 & - & 15.3 & 0.80 \\
\hline
\end{tabular}

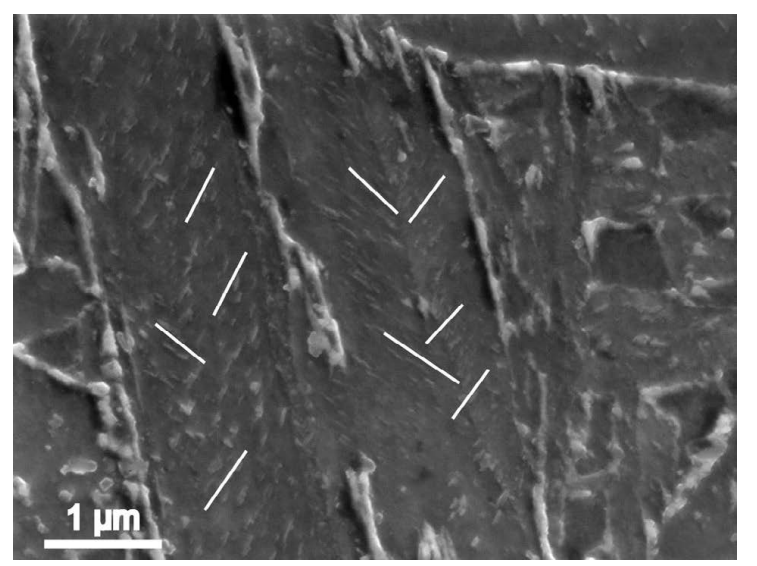

Fig. 5. Laths of self-tempered martensite (presence of carbides) observed by SEM in the $\mathrm{C} 3$ microstructure obtained by austempering at $\mathrm{Ms}-50^{\circ} \mathrm{C}$. The direction of the multiple carbide orientation variants has been highlighted. 
proceeded. The mean carbon content of the retained austenite was thus calculated from the balance of carbon in each phase. Since the solubility of carbon in the bainitic ferrite is very low at such temperatures, assumptions were made to consider that all the carbon could diffuse from the bainitic ferrite into the neighboring austenite. As martensite was tempered during the austempering stage (as shown in Fig. 5), we assumed that all the carbon of the tempered martensite should have precipitated into carbides and no partition of carbon between martensite and austenite should have occurred. Besides, the applied austempering treatment differed significantly from the quench and partitioning (Q\&P) process introduced by Edmonds et al., ${ }^{3)}$ in which austenite is carbon enriched through partitioning from the martensite. Figure 6 shows a schematic illustration of the role of carbon during a $\mathrm{Q} \& \mathrm{P}$ and an austempering processes adapted to the grade $\mathrm{C} 2$. The partition of carbon between martensite and austenite should only occur if the partitioning stage is performed at temperatures above the quench temperature (usually above Ms); otherwise transition carbides should form into the martensitic laths. ${ }^{3)}$ Moreover, as illustrated on Fig. 6 , the influence of $\mathrm{Si}$ on carbides precipitation differs between the two modes of carbon distribution: only cementite precipitation should be strongly delayed. Therefore, the carbon content of the tempered martensite was assumed to be the same as the initial carbon content of the austenite $\left(C_{\alpha_{S T}}^{C}=C_{0}\right.$ ), although a negligible portion of carbon could have diffused into the retained austenite.

This led to a good assessment of the evolution of the carbon content in the retained austenite for different heat treatments. Equation (1) gives the formula used for this calculation (where $C_{0}$ is the initial carbon content in the steel, $f_{\gamma}$ is the volume fraction of retained austenite, $C_{\gamma}^{C}$ is the carbon content in the retained austenite, $f_{\alpha_{s t}}$ is the volume fraction of self-tempered martensite and $C_{\alpha_{S T}}^{C}=C_{0}$ is the carbon content in the tempered martensite):

$$
C_{\gamma}^{C}=\frac{C_{0}-f_{\alpha_{S T}} C_{\alpha_{S T}}^{C}}{f_{\gamma}}=C_{0} \frac{1-f_{\alpha_{S T}}}{f_{\gamma}}
$$

Observations of the inherited microstructures were performed on the KPQ EBSD maps. Figure 7 shows some of these maps for the steel $\mathrm{C} 3$ at different $\mathrm{AT}\left(\mathrm{Ms}-50^{\circ} \mathrm{C}, \mathrm{Ms}\right.$ and $\mathrm{Ms}+50^{\circ} \mathrm{C}$ ). The morphology of the bainitic matrix was effortlessly visible. MA blocks were clearly identified at

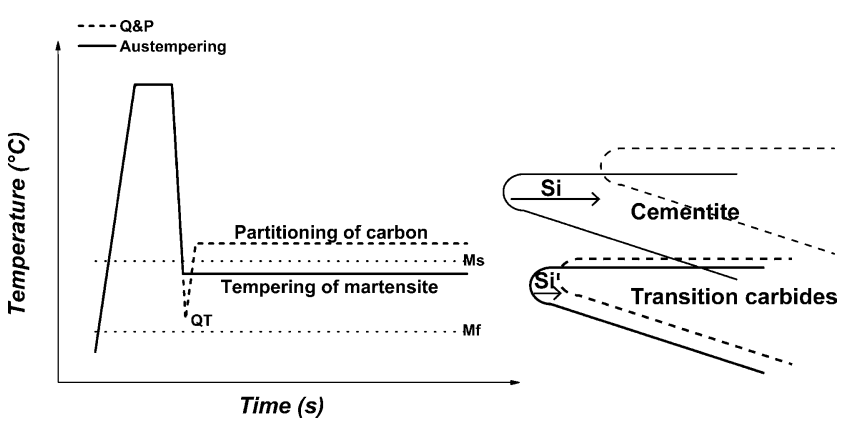

Fig. 6. Schematic illustration of the differences between an austempering and a quench and partitioning processes adapted to the $\mathrm{C} 2$ grade. Schematic C-curves of cementite and transition carbides have been added with the effect of Si on their kinetics, after Edmonds et $a l^{3)}$ high AT, but needed more resolution at low AT, especially at $\mathrm{Ms}-50^{\circ} \mathrm{C}$ where they were smaller than $2 \mu \mathrm{m}^{2}$. Despite the good spatial resolution of the FEG-SEM and the good precision of the EBSD system, it was quite difficult to index retained austenite in the microstructures, since it was mainly located as thin films between bainitic ferrite laths or in the MA blocks, hard to index due to high stress state. Transmission electron microscopy should be more suitable to characterize nanoscale films of retained austenite..$^{25,26)}$

For $\mathrm{AT}=\mathrm{Ms}-50^{\circ} \mathrm{C}$, the matrix was mainly constituted of self-tempered martensite $(\sim 65 \%)$. The bainitic transformation led to approximately $20 \%$ of bainitic ferrite until the stasis is reached, which ensured that the carbon enrichment of the austenite would be sufficient to stabilize it at room temperature. The retained austenite mainly formed as thin films between martensitic or bainitic laths. Therefore, only rare and small MA blocks were observed near the previous
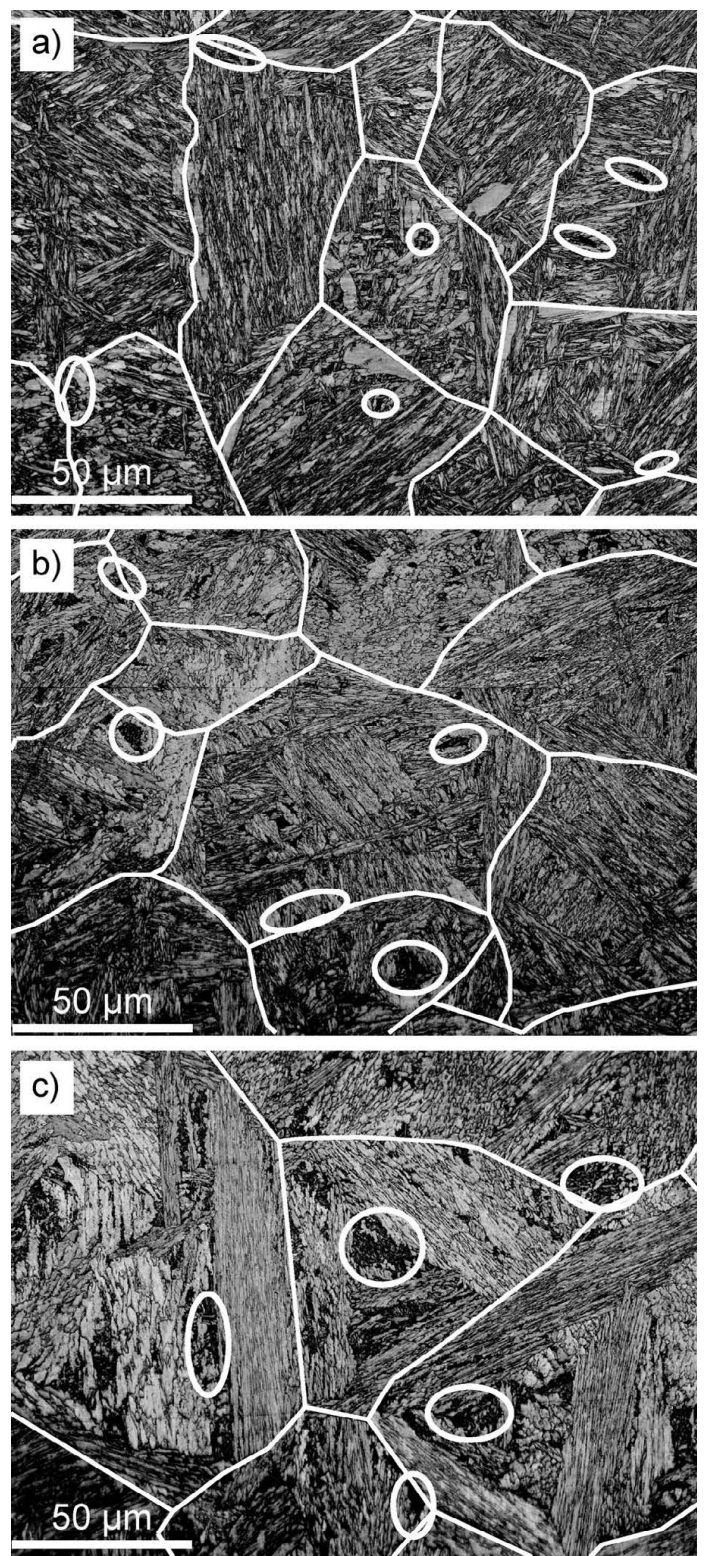

Fig. 7. Kikuchi Pattern Quality maps (grey scale) of the C3 grade elaborated at different austempering temperatures: a) Ms$50^{\circ} \mathrm{C}$, b) $\mathrm{Ms}$ and c) $\mathrm{Ms}+50^{\circ} \mathrm{C}$. Prior austenitic grain boundaries have been highlighted (white lines) as well as some MA blocks (white circles). 
Table 3. Mean bainitic lath width measured by the intercept method from the HKL software Channel 5 (Critical misorientation angle $=5^{\circ}$ ).

\begin{tabular}{ccccccc}
\hline Steel & \multicolumn{3}{c}{$\mathrm{C} 2$} & \multicolumn{3}{c}{$\mathrm{C} 3$} \\
\hline AT & $\mathrm{Ms}-50^{\circ} \mathrm{C}$ & $\mathrm{Ms}$ & $\mathrm{Ms}+50^{\circ} \mathrm{C}$ & $\mathrm{Ms}-50^{\circ} \mathrm{C}$ & $\mathrm{Ms}$ & $\mathrm{Ms}+50^{\circ} \mathrm{C}$ \\
$l_{0}$ & 0.52 & 0.40 & 0.81 & 0.32 & 0.44 & 0.65 \\
\hline
\end{tabular}

austenitic grain boundaries (less than $2 \mu \mathrm{m}^{2}$ ). It led conclusively to a small amount of retained austenite transformed into fresh martensite during the final cooling at room temperature (up to $1.1 \%$ for the heat $\mathrm{C} 3$ ).

For $\mathrm{AT}=\mathrm{Ms}$, the bainitic matrix constituted about $80 \%$ of the microstructure. The retained austenite mainly formed as thin films between bainitic laths and was strongly enriched in carbon (up to 1.5\%). Small amounts of self-tempered martensite also formed before reaching the austempering stage because of an overshoot of $5-8^{\circ} \mathrm{C}$ below Ms. Small MA blocks were observed near the previous austenitic grain boundaries, with less than $5 \%$ of fresh martensite.

For $\mathrm{AT}=\mathrm{Ms}+50^{\circ} \mathrm{C}$, the microstructure showed dissimilarities with the one austempered at Ms. Higher volume fractions of retained austenite and of fresh martensite were observed. In agreement with the $\mathrm{T} 0$ ' theory, ${ }^{27)}$ the retained austenite held less carbon than the one elaborated at Ms, which is consistent with larger observed MA blocks. In the case of the $\mathrm{C} 2$ heat, the carbon enrichment of the retained austenite was not sufficient to stabilize it at room temperature. Therefore, the volume fraction of fresh martensite skyrocketed at the expense of the volume fraction of retained austenite at room temperature.

KPQ maps also allowed to point out significant microstructural features such as the mean bainitic lath width (measured by the intercept method with the HKL Channel 5 software, using a critical misorientation angle of $5^{\circ}$ ). Results are reported in Table 3. It should be noted that the intercept method used on lamellar structures required corrections to reflect the real lath width. We used two corrections, as reported by Zhu et al. ${ }^{28)}$ to measure the mean bainitic lath width. Equation (2) gives this relationship:

$$
l_{0}=0.32 l^{\prime}
$$

where $l$ ' is the measured intercept and $l_{0}$ the effective lath size.

The EBSD analysis also gave fruitful information on the microtexture. Only minor differences were observed between the microstructures elaborated at different AT. Moreover, they exhibited crystallographic characteristics similar to lower bainite, i.e. all misorientation angle distributions showed a large peak at $60^{\circ}\left(\right.$ Fig. 8) ${ }^{29)}$

These distributions of misorientation angles were inherited from the bainitic transformation. There are indeed two main orientation relationships found in the $\gamma \rightarrow \alpha$ phase transformation: the one from Kurdjumov - Sachs (KS) and the one from Nishiyama - Wassermann (NW). Each of them induces specific misorientation relationships (MR) between variants of bainitic ferrite formed in the same prior austenitic grain. ${ }^{30,31)}$ Moreover, a spatial variant selection could occur during the formation of bainitic ferrite laths. In the case of lower bainite and martensite, it promotes a set of
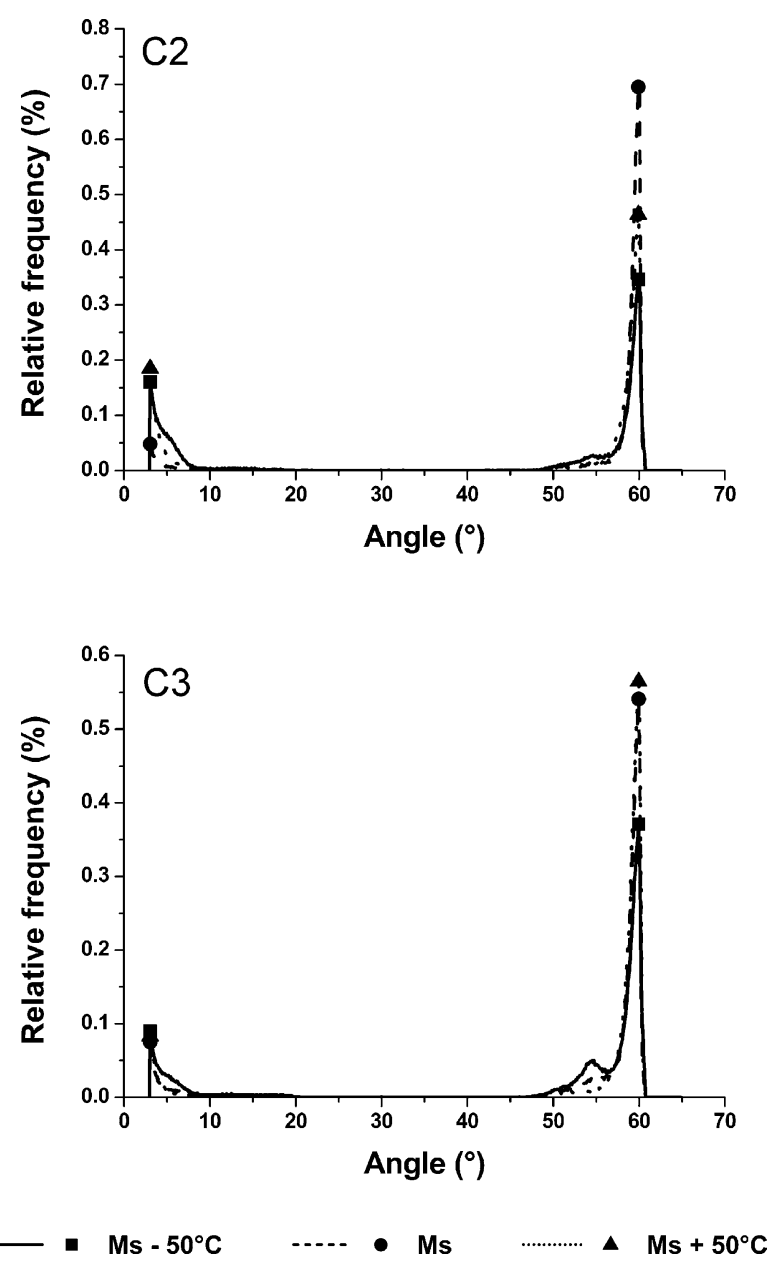

Fig. 8. Misorientation angles distribution for the heats $\mathrm{C} 2$ and $\mathrm{C} 3$ elaborated at different austempering temperatures.

highly misorientated variants to accommodate the shape strains induced by the phase transformation. ${ }^{30)}$ This induces a strong peak at $60^{\circ}$ on the misorientation angles distribution.

The main MR found between bainitic ferrite laths could be characterized by a pair (angle - axes) of $\left(60.2^{\circ}-<433>\right.$ ) and $\left(60^{\circ}-<111>\right)$. The MR characterized by $\left(60.2^{\circ}-\right.$ $<433>$ ) matched a misorientation observed between two bainitic ferrite variants inherited respectively from KS and from NW, whereas the one characterized by $\left(60^{\circ}-<111>\right)$ matched the twin relation commonly found in martensitic microstructures. Minor differences in the distribution of the two main MR were observed between the microstructures austempered at different temperatures. Microstructures austempered at Ms and above exhibited a higher fraction of MR characterized by $\left(60.2^{\circ}-<433>\right)$, while those austempered below Ms exhibited a higher fraction of MR characterized by $\left(60^{\circ}-<111>\right)$.

\subsection{Tensile Properties}

The tensile test results are summarized in Table 4 and the tensile curves are shown in Fig. 9. All grades reached high tensile strengths (above $1250 \mathrm{MPa}$ ) and significant ductility (uniform elongation above 6\%). Work hardening coefficients were calculated from the Ludwig - Hollomon hardening law. ${ }^{32)}$

The $\mathrm{C} 3$ heat austempered at $\mathrm{Ms}+50^{\circ} \mathrm{C}$ showed the highest 
Table 4. Results of the tensile tests (ultimate tensile strength - UTS and yield strength - YS, uniform elongation - UEl and total elongation - TEl, and the reduction of section area at fracture - RA).

\begin{tabular}{llcccccc}
\hline \multirow{2}{*}{ Steel } & \multicolumn{1}{c}{$\mathrm{AT}$} & $\begin{array}{c}\text { YS } \\
(\mathrm{MPa})\end{array}$ & $\begin{array}{c}\text { UTS } \\
(\mathrm{MPa})\end{array}$ & $\begin{array}{c}\text { UEl } \\
(\%)\end{array}$ & $\begin{array}{c}\text { TEl } \\
(\%)\end{array}$ & $\begin{array}{c}\text { RA } \\
(\%)\end{array}$ & $\mathrm{n}$ \\
\hline \multirow{2}{*}{$\mathrm{C} 2$} & $\mathrm{Ms}-50^{\circ} \mathrm{C}$ & 969 & 1290 & 6.6 & 15.1 & 46 & 0.28 \\
& $\mathrm{Ms}$ & 851 & 1300 & 8.6 & 17.9 & 41 & 0.31 \\
& $\mathrm{Ms}+50^{\circ} \mathrm{C}$ & 835 & 1360 & 7.9 & 13.2 & 29 & 0.33 \\
& $\mathrm{Ms}-50^{\circ} \mathrm{C}$ & 911 & 1570 & 7.9 & 15.2 & 37 & 0.24 \\
& $\mathrm{Ms}$ & 975 & 1490 & 7.6 & 15.4 & 39 & 0.25 \\
& $\mathrm{Ms}+50^{\circ} \mathrm{C}$ & 797 & 1400 & 13.4 & 19.6 & 30 & 0.36 \\
\hline
\end{tabular}
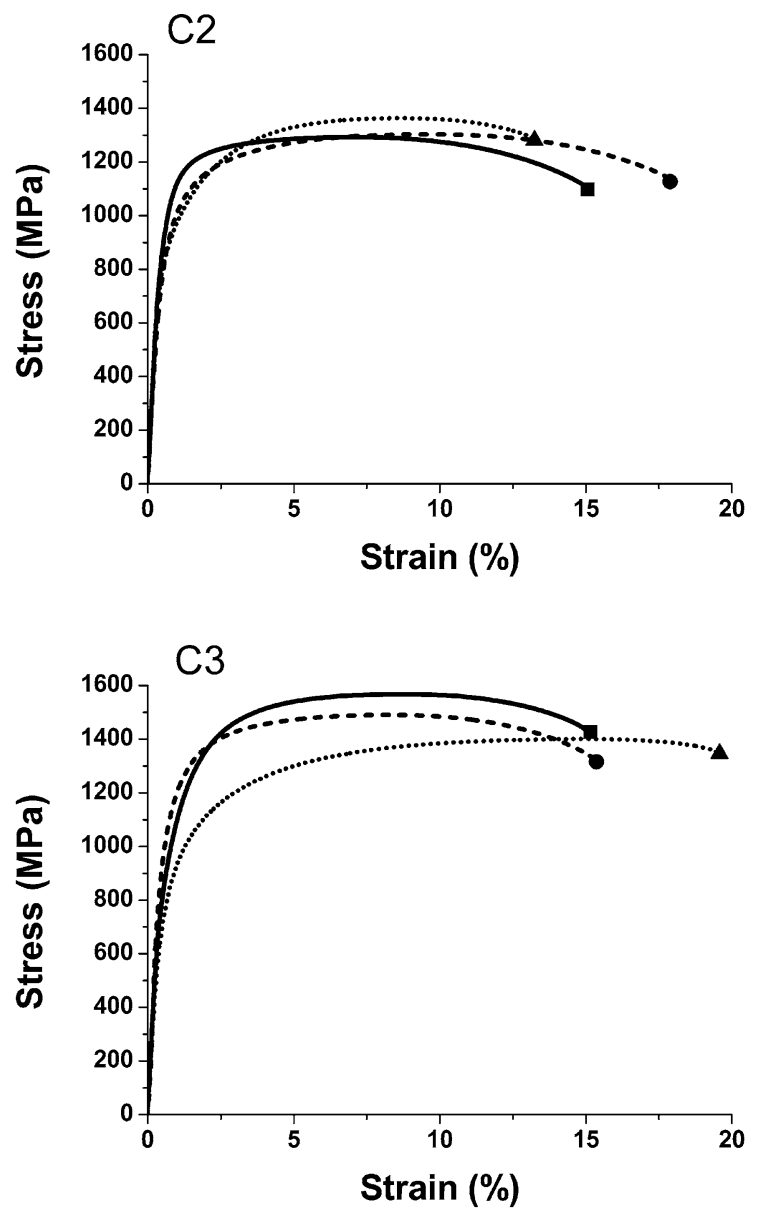

- $M s-50^{\circ} \mathrm{C}$

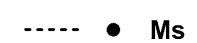

.......... $\triangle \mathrm{Ms}+50^{\circ} \mathrm{C}$

Fig. 9. Engineering tensile curves obtained for both grades.

uniform and total elongation amongst all the elaborated microstructures, but slightly lower yield and ultimate tensile strengths. Such ductility is consistent with a TRansformation Induced Plasticity (TRIP) effect, especially because of the high volume fraction of retained austenite in this microstructure and their lower carbon content. In-situ measurements of the volume fraction of retained austenite were then performed during tensile tests by high energy synchrotron diffraction. The tensile tests were performed at very slow strain rate $\left(10^{-4} \mathrm{~s}^{-1}\right)$ and at room temperature. Figure 10 presents the evolution of the volume fraction of retained austenite and the applied stress, until the uniform elongation was

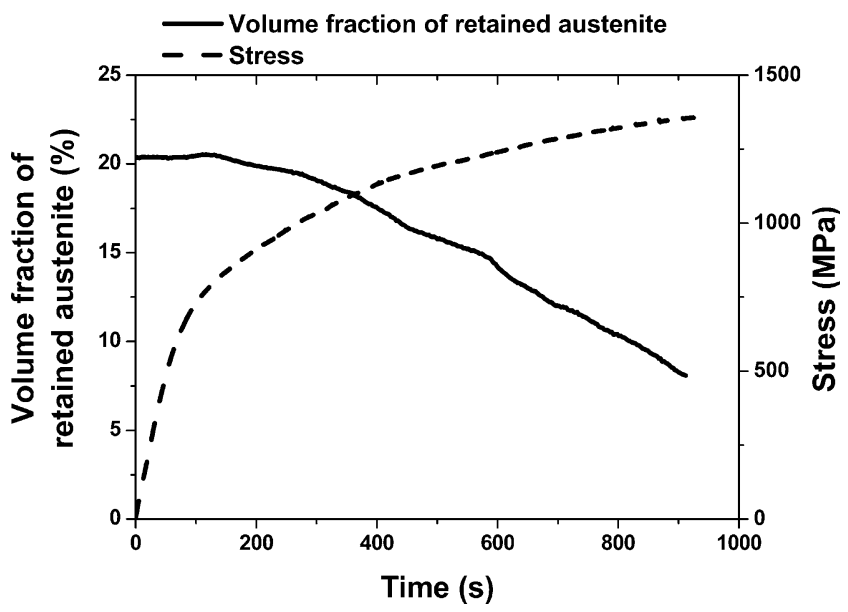

Fig. 10. Evolution of the volume fraction of retained austenite and applied stress until uniform elongation as a function of time during in-situ tensile test at very slow strain rate $\left(10^{-4} \mathrm{~s}^{-1}\right)$ on the $\mathrm{C} 3$ grade austempered at $\mathrm{Ms}+50^{\circ} \mathrm{C}$.

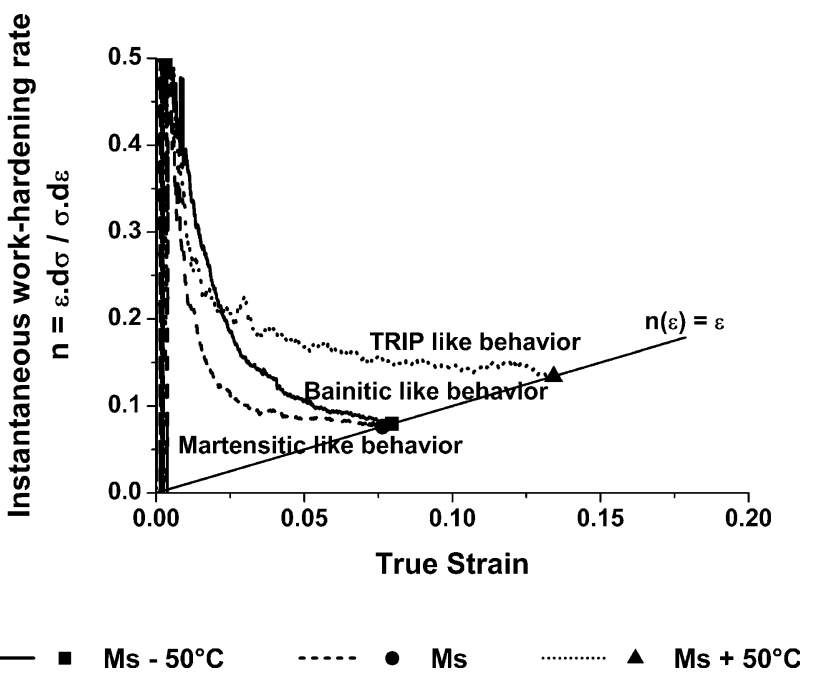

Fig. 11. Instantaneous work hardening rate vs. true strain for the C3 grade austempered at different temperatures.

reached, as a function of time.

Retained austenite transformed into martensite shortly after the end of the elastic yielding. The evolution of the volume fraction of retained austenite showed a continuous decrease $\left(f_{\gamma R}: 20.4 \% \rightarrow 8.1 \%\right)$ which confirmed the existence of a TRIP effect in this microstructure.

\section{Discussion}

\subsection{Work-hardening at Low Strain (until Uniform Elongation)}

The CFB steels elaborated in this study presented interesting mechanical behaviors, especially for the $\mathrm{C} 3$ grade austempered at $\mathrm{Ms}+50^{\circ} \mathrm{C}$. The instantaneous work hardening rates were calculated by a moving average interpolation from all tensile data. Figure 11 presents these results for the $\mathrm{C} 3$ grade. The treatment at $\mathrm{Ms}+50^{\circ} \mathrm{C}$ led indeed to a higher uniform elongation than the treatments at Ms and below. It also exhibited a work hardening behavior similar to TRIP steels, as shown by the evolution of the instantaneous workhardening rate, while heats austempered at Ms and below 
exhibited behaviors closer to martensitic (austempered at $\mathrm{Ms}-50^{\circ} \mathrm{C}$ ) or bainitic (austempered at $\mathrm{Ms}$ ) steels. ${ }^{33 \text { ) }}$

\subsection{Work-hardening at High Strain}

The mechanical behavior of the CFB steels at high strain was characterized by measuring the reduction of area from the broken tensile samples, leading to the true strains and true stresses at fracture. Results are presented in Fig. 12. Both steels exhibited very high fracture strains (all above $40 \%$ ) and stresses (all above $2000 \mathrm{MPa}$ ). The treatment at $\mathrm{Ms}-50^{\circ} \mathrm{C}$ led to the highest fracture strain, up to $60 \%$ in the case of the grade $\mathrm{C} 2$. The work-hardening at high strain were consistent with the Bridgman extrapolation procedure, ${ }^{34,35)}$ where the plastic yielding is extrapolated linearly from the Considère's criterion. ${ }^{36)}$ Equation (3) gives the formula used for this extrapolation (where $\sigma_{R A}$ is the stress at fracture, $\epsilon_{R A}$ is the strain at fracture assessed from the reduction of area measured at fracture, and $\sigma_{C}$ and $\epsilon_{C}$ are the stress and strain at the Considère's criterion):

$$
\sigma_{R A}=\sigma_{C} \times\left[1+\left(\epsilon_{R A}-\epsilon_{C}\right)\right]
$$

It is also noticeable that both grades presented slightly different behaviors when austempered at $\mathrm{Ms}+50^{\circ} \mathrm{C}$. The $\mathrm{C} 2$ steel exhibited indeed lower work hardening than the $\mathrm{C} 3$
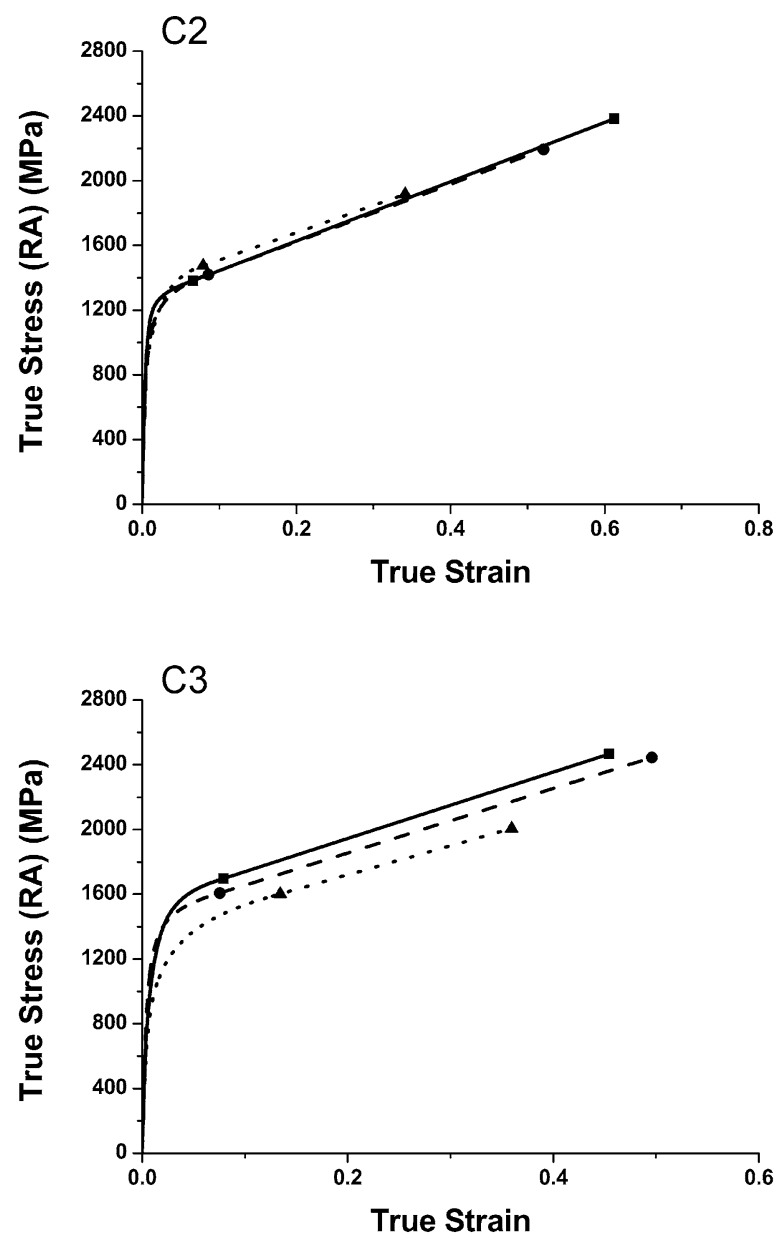

- $\mathrm{Ms}-50^{\circ} \mathrm{C}$

Fig. 12. True stress - strain tensile curves. Fracture stresses and strains were calculated from the measurements of the reduction of area at fracture. grade, even if their fracture strains and stresses were nearly the same. This could be explained by the higher volume fraction of fresh martensite and MA blocks observed in the C2 steel austempered at this temperature and by the TRIP effect observed in the C3 grade (Fig. 10).

\subsection{Fracture Behavior and Microstructure - Proper- ties Relationships}

The fracture surfaces of the CFB steels were investigated thanks to scanning electron microscopy. Results showed ductile behavior for all the samples, except for the $\mathrm{C} 2$ heat austempered at $\mathrm{Ms}+50^{\circ} \mathrm{C}$. Figure 13 presents two typical fracture surfaces, where dimples were observed in the $\mathrm{C} 3$ heat (ductile behavior) and cleavage in the heat $\mathrm{C} 2$ (brittle behavior), both austempered at $\mathrm{Ms}+50^{\circ} \mathrm{C}$.

The sides of the specimens were also observed by SEM, revealing a network of cracks just below the fracture surface for all samples exhibiting ductile behavior. Moreover, cracks seemed to follow the previous austenitic grain boundaries and were of a ductile nature. Two damaging mechanisms were identified: one purely intergranular and another transgranular process. Figure 14 shows the crack networks observed, as well as intergranular and transgranular cracks observed near previous austenitic grain boundaries. The fracture usually initiated by decohesion between the prior austenitic grain boundaries and MA blocks located at these boundaries.
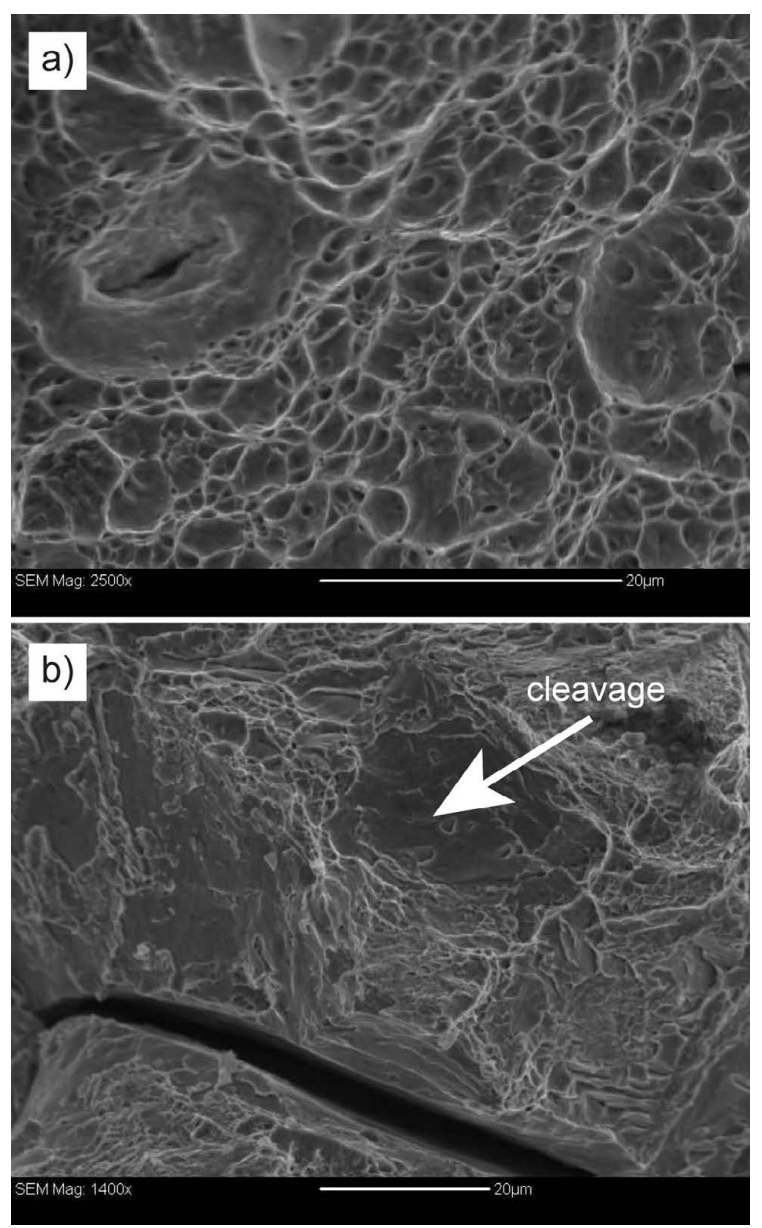

Fig. 13. Fracture surfaces of: a) $\mathrm{C} 3$ austempered at $\mathrm{Ms}+50^{\circ} \mathrm{C}$ (ductile behavior) and b) $\mathrm{C} 2$ austempered at $\mathrm{Ms}+50^{\circ} \mathrm{C}$ (brittle behavior). 

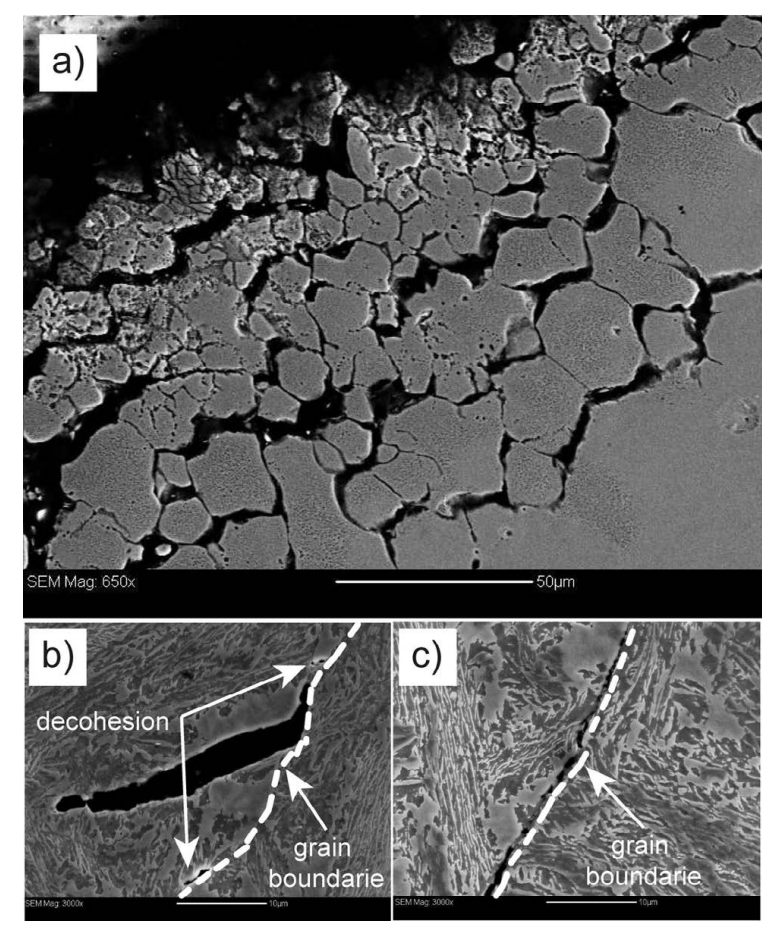

Fig. 14. a) Fracture network observed on the surface just below the fracture. Two mechanisms of fracture identified: b) transgranular and c) intergranular.

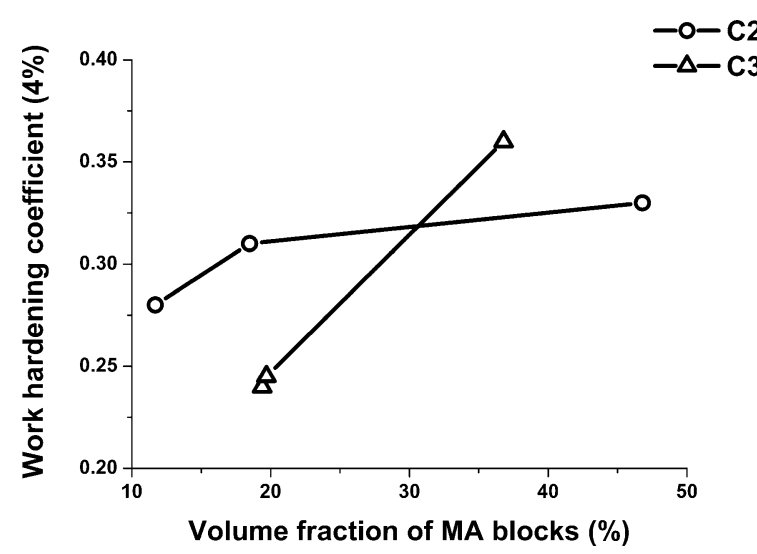

Fig. 15. Influence of the volume fraction of MA blocks on the work hardening coefficient calculated from Ludwig Hollomon hardening law.

MA blocks appeared therefore as privileged damaging sites which reduced the fracture strain. The influence of MA blocks on the mechanical behavior was then studied to go further into the understanding of the differences observed on the mechanical properties of these steels. Figure 15 shows the influence of the volume fraction of MA blocks on the work hardening coefficient. High volume fractions of MA blocks enhanced the work hardening coefficient, which is consistent with the behavior observed at high strain. Moreover, the $\mathrm{C} 3$ grade elaborated at $\mathrm{Ms}+50^{\circ} \mathrm{C}$ exhibited higher work hardening coefficient than the ones austempered at lower temperatures or than the $\mathrm{C} 2$ grade. This increase was actually related to the TRIP effect observed in this steel.

Figure 16 shows the relationships between the volume fraction of MA blocks and the reduction of area measured at fracture. These two parameters appeared clearly related

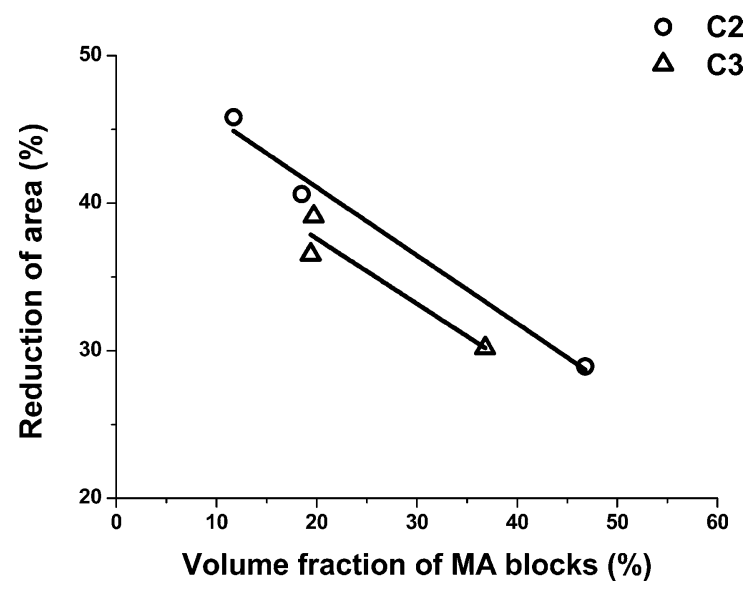

Fig. 16. Evolution of the reduction of area at fracture as a function of the volume fraction of MA blocks.

for both grades. Moreover, linear interpolations between experimental points gave similar slope for both steels. The volume fraction of MA blocks seemed subsequently to be a relevant parameter that has a strong impact on the workhardening at the expense of the damaging properties.

\section{Conclusion}

Two carbide-free bainitic steels were elaborated through specific alloy design and thermomechanical processing. The characterizations of their microstructures, as well as their microtextures, were performed, in parallel with the characterization of their tensile properties. Despite the fact that the microtextures of these grades were similar (lower bainite type), even in a given heat austempered at different temperatures, their microstructures showed some differences:

- on the nature of their matrix: fully bainitic above Ms, and mainly self-tempered martensite below Ms,

- on the volume fractions of retained austenite and MA blocks, formed during the final cooling.

Moreover, austempering below Ms led to the formation of a detectable amount of bainitic ferrite and to the carbonenrichment of the retained austenite.

Both steels exhibited excellent balances of high tensile strength (UTS > $1250 \mathrm{MPa}$ ), good ductility (UEL > 6\%) and fracture strain (RA up to $46 \%$ ). The heat $\mathrm{C} 3$ elaborated at $\mathrm{Ms}+50^{\circ} \mathrm{C}$ presented the most interesting behavior, with very high ultimate tensile strength $(1400 \mathrm{MPa})$ and high uniform elongation (14\%) due to a TRIP effect. The CFB steels have also shown a promising work-hardening behavior at high strain, with very high fracture stresses, above $2000 \mathrm{MPa}$, and very high fracture strains, up to $60 \%$. We have also identified the strong influence of the volume fraction of MA blocks on the work-hardening, although they stand as privileged damaging sites inhibiting the damaging properties.

\section{Acknowledgements}

The authors gratefully acknowledge the ESRF (Grenoble, France) for the synchrotron facilities and for the provision of beamtime. The authors would like to thank Mrs. Francisca Garcia Caballero and her colleagues from the CENIM, for fruitful discussions. 


\section{REFERENCES}

1) D. K. Matlock and J. G. Speer: Microstructure and Texture in Steels and Other Materials, ed. by A. Haldar, S. Suwas and D. Bhattacharjee, Springer-Verlag London Ltd, Jamshedpur, INDIA (2009), 185.

2) M. J. Santofimia, T. Nguyen-Minh, L. Zhao, R. Petrov, I. Sabirov and J. Sietsma: Mater. Sci. Eng. A, 527 (2010), 6429.

3) D. Edmonds, K. He, F. Rizzo, B. Decooman, D. Matlock and J. Speer: Mater. Sci. Eng. A, 438-440 (2006), 25.

4) F. Caballero and H. Bhadeshia: Curr. Opin. Solid State Mater. Sci., 8 (2004), 251.

5) C. Garcia Mateo, F. Caballero and H. Bhadeshia: ISIJ Int., 43 (2003), 1238.

6) K. Sugimoto, K. Nakano, S. Song and T. Kashima: ISIJ Int., 42 (2002), 450.

7) K. Sugimoto, M. Tsunezawa, T. Hojo and S. Ikeda: ISIJ Int., 44 (2004), 1608

8) I. B. Timokhina, P. D. Hodgson and E. V. Pereloma: Metall. Mater. Trans. A, 35A (2004), 2331.

9) E. Pereloma, I. Timokhina, M. Miller and P. Hodgson: Acta Mater., 55 (2007), 2587.

10) M. Soliman and H. Palkowski: ISIJ Int., 47(2007), 1703.

11) T. S. Wang, J. Yang, C. J. Shang, X. Y. Li, B. Zhang and F. C. Zhang: Scr. Mater., 61 (2009), 434.

12) F. G. Caballero, J. Chao, J. Cornide, C. García-Mateo, M. J. Santofimia and C. Capdevila: Mater. Sci. Eng. A, 525 (2009), 87.

13) C. Garcia de Andres: Mater. Charact., 49 (2002), 121.

14) D. San Martín, Y. Palizdar, R. C. Cochrane, R. Brydson and A. J. Scott: Mater. Charact., 61 (2010), 584.

15) W. T. Reynolds, S. K. Liu, F. Z. Li, S. Hartfield and H. I. Aaronson: Metall. Trans. A, 21 (1990), 1479.

16) H. Bhadeshia and A. Waugh: Acta Metall., 30 (1981), 775.

17) F. Caballero, M. Santofimia, C. Capdevila, C. Garcia Mateo and C. Garcia de Andres: ISIJ Int., 46 (2006), 1479.

18) X. D. Wang, B. X. Huang, L. Wang and Y. H. Rong: Metall. Mater. Trans. A, 39 (2008), 1.
19) J. C. Hell, M. Dehmas, G. Geandier, N. Gey, S. Allain, A. Hazotte and J. P. Chateau: PTM 2010, Solid State Phenomena, Avignon, France, (2011), accepted publication: 01/03/2011

20) H. Rietveld: J. Appl. Crystallgr., 2 (1969), 65.

21) D. H. Kim, J. G. Speer, H. S. Kim and B. C. Cooman: Metall. Mater. Trans. A, 40 (2009), 2048.

22) S. Vanbohemen, M. Santofimia and J. Sietsma: Scr. Mater., 58 (2008), 488.

23) H. J. Stone, M. J. Peet, H. K. D. H. Bhadeshia, P. J. Withers, S. S. Babu and E. D. Specht: Proc. of the Royal Society A, 464 (2008), 1009.

24) E. Vuorinen and X. Chen: Mater. Sci. Forum, 638-642 (2010), 3086.

25) H. Beladi, Y. Adachi, I. Timokhina and P. Hodgson: Scr. Mater., 60 (2009), 455.

26) J. J. Fundenberger, A. Morawiec, E. Bouzy and J. S. Lecomte: Ultramicroscopy, 96 (2003), 127.

27) H. Bhadeshia and J. Christian: Metall. Mater. Trans. A, 21 (1990), 767.

28) K. Zhu, O. Bouaziz, C. Oberbillig and M. Huang: Mater. Sci. Eng. A, 527 (2010), 6614

29) S. Zajac, V. Schwinn and K. Tacke: Mater. Sci. Forum, 500-501 (2005), 387.

30) A. F. Gourgues, H. M. Flower and T. C. Lindley: Mater. Sci. Technol., 16 (2000), 26

31) M. Humbert, P. Blaineau, L. Germain and N. Gey: Scr. Mater., 64 (2011), 114

32) H. W. Hayden, W. G. Mofatt and J. Wulff: The structure and properties of materials, vol. III: Mechanical behavior, John Wiley and Sons, New York, (1965).

33) S. Allain and T. Iung: Rev. Metall., 105 (2008), 520.

34) P. W. Bridgman: Studies in large plastic flow and fracture, McGraw - Hill, New York, (1952).

35) K. S. Zhang and Z. H. Li: Eng. Fract. Mech., 49 (1994), 235.

36) A. Considère: Annales des Ponts et Chaussées, Mémoire sur l'emploi du fer et de l'acier dans les constructions, Vol. IX, ed. by C. Dunod, Typographie J. Leclerc, Paris, (1885), 574. 